\title{
Trends in Crop Reference Evapotranspiration and Climatological Variables Across Ceará State - Brazil
}

\author{
Virginia Ellen do Nascimento Paulino ${ }^{1}$, Ticiana Marinho de Carvalho Studart ${ }^{1}$ (D), \\ José Nilson B. Campos ${ }^{1}$, Carlos J. Pestana ${ }^{1}$, Renata Mendes Luna ${ }^{1}$, José Maria Brabo Alves ${ }^{2}$ \\ ${ }^{1}$ Departamento de Engenharia Hidráulica e Ambiental, Universidade Federal do Ceará, \\ Fortaleza, CE, Brasil. \\ ${ }^{2}$ Departamento de Física, Universidade Estadual do Ceará, Fortaleza, CE, Brasil.
}

Received: 31 May 2018 - Accepted: 4 October 2018

\begin{abstract}
Irrigation has a substantial share in total world water demand. At the global level, the withdrawal ratio for agriculture is 69 percent. Irrigation is necessary to compensate evapotranspiration (ET) deficit due to insufficient precipitation. Knowing the impacts of climatic changes on meteorological variables that directly affect the ET is important for successful climate adaptation. This paper analyzes annual trends in measured meteorological variables and in the crop reference evapotranspiration $\left(\mathrm{ET}_{0}\right)$, at eight climatological stations in Ceará State, Brazil. Two statistical tests for trend analysis were used - Mann-Kendall and linear regression. The results indicate positive trend, statistically significant, in the maximum air temperature in five of eight stations. Minimum air temperature showed positive trend in three stations. Wind speed, sunshine hours and relative humidity presented positive and negative trends. These irregular patterns directly impacted $\mathrm{ET}_{0}$ in three stations. It seems that the increasing trend in $\mathrm{ET}_{0}$ was probably due to a significant increase detected in maximum temperature and minimum air temperature, not fully offset by the decrease in wind speed and relative humidity. The warning from these results is that water demand for irrigation is expected to significantly increase over the next decades on in Jaguaribe River Basin.
\end{abstract}

Keywords: Mann-Kendall, linear regression, semi-arid.

\section{Análise de Tendências na Evapotranspiração de Referência e nas Variáveis Climatológicas do Estado do Ceará-Brasil}

\begin{abstract}
Resumo
A irrigação representa uma parte substancial na demanda de água mundial. Em âmbito global, a retirada para a agricultura é de $69 \%$. A irrigação é necessária para compensar o déficit em evapotranspiração (ET) devido à precipitação insuficiente. $\mathrm{O}$ conhecimento dos impactos das mudanças climáticas em variáveis meteorológicas que afetam a ET é importante para adaptação às mudanças no clima. Este artigo analisa tendências em variáveis meteorológicas e na evapotranspiração de referência $\left(\mathrm{ET}_{0}\right)$, em oito estações climatológicos no estado do Ceará, Brasil. Foram aplicados os testes de Mann-Kendall e regressão linear. Os resultados indicam tendência positiva, estatisticamente significativa, na temperatura máxima do ar, em cinco de oito estações. A temperatura mínima do ar mostrou tendência positiva em três estações. A velocidade do vento, as horas de insolação e a umidade relativa apresentaram tendências positivas e negativas. Estes padrões impactaram a $\mathrm{ET}_{0}$ em três estações. A tendência crescente em $\mathrm{ET}_{0}$ decorre do aumento detectado na temperatura máxima e na temperatura mínima do ar, não totalmente compensado pela diminuição na velocidade do vento e na umidade relativa. Estes resultados apontam para aumento da demanda para irrigação nas próximas décadas sobre na bacia do rio de Jaguaribe.
\end{abstract}

Palavras-chave: Mann-Kendall, regressão linear, semiárido.

Autor de Correspondência: Ticiana Marinho de Carvalho Studart, ticianastudart2010@gmail.com. 


\section{Introduction}

Irrigation is an essential driving force in the water use management and has a substantial share in total world water demand. At global level, the withdrawal ratios are $69 \%$ agricultural (including irrigation, livestock and aquaculture), 12\% municipal (including domestic) and 19\% industrial (FAO, 2016). In arid and semiarid climates or during extended dry seasons, irrigation is necessary to compensate evapotranspiration (ET) deficit due to insufficient precipitation.

ET is one of the critical components of the hydrological cycle, given its importance for local water availability estimation. A report of the Intergovernmental Panel on Climate Change (IPCC, 2014) shows that, in recent decades, the near-surface air temperature has increased significantly. This results in higher evaporation rates, which enables higher amounts of water vapor to be transported by the atmosphere. The main warning from these results is that water demand for irrigation is expected to significantly increase over the next decades due higher ET rates.

Measuring ET directly is a complicated task due to the varied factors that influence it, one must consider parameters that affect the plant (crop type, variety, density and phase culture), the soil (salinity, fertility, presence/ absence of disease and the local weather). Thus, surrogate measurements obtained from meteorological variables (air temperature, wind speed, humidity and solar radiation) are used to indirectly compute the reference evapotranspiration or reference crop evapotranspiration, denoted as $\mathrm{ET}_{0}$ (Temesgen et al., 2005).

According to Shan et al. (2015), $\mathrm{ET}_{0}$ is one of the best indicators of hydrological processes changes. From the results of IPCC (2014), it can be expected that the water cycle has accelerated in many parts of the world ( $\mathrm{LV}$ et al., 2016). Despite some recent studies confirming the expectation of $\mathrm{ET}_{0}$ increase is associated to average temperature elevation (Dinpashoh et al., 2011; Tabari et al., 2012), other studies point in the opposite direction (Xu et al., 2006; Kousari et al., 2013; Huo et al., 2013; Li et al., 2013; Shan et al., 2015), possibly due to atmospheric changes in other variables. Peterson et al. (1995) linked the decrease in $\mathrm{ET}_{0}$ in the US and in the former Soviet Union to increases in cloud cover, which influenced the radiation balance; Bandyopadhyay et al. (2009) related the decrease in $\mathrm{ET}_{0}$ in India to increases in the relative humidity, coupled with decreases in solar radiation and wind speeds.

Several studies have also analyzed the $\mathrm{ET}_{0}$ in Brazil. A large majority, however, were based on Climatological Standard Normal (1961-1990), published by the National Institute of Meteorology - INMET. In 2016, INMET released a new historical database of all Brazilian meteorological stations, including 1990 - 2015 period.

In this context, the objective of this paper is to analyze spatial and temporal variations in five meteorological variables that directly affect the $\mathrm{ET}_{0}$ : maximum and minimum temperature, wind speed, insolation, and relative humidity. Additionally, changes in the $\mathrm{ET}_{0}$ itself have been estimated using the Pemann-Montheith (PM) method. The dataset used covers the period from 1961 to 2015 , identifying possible trends in these variables and in $\mathrm{ET}_{0}$ across Ceará State, Brazil, a region of semiarid climate, frequently plagued by droughts. Knowing the impacts of climatic changes on water demand for irrigation and high-water consumption activity is very important for successful climate adaptation. This is especially true for semi-arid regions (Alves et al., 2009).

\section{Materials and Methods}

\subsection{Study area}

The State of Ceará, in the semi-arid Northeast of Brazil, has a short rainy season. The three large-scale precipitation mechanisms - Intertropical Convergence Zone (ITCZ), cold fronts, and upper air vortices - create a certain rainfall pattern over the state during different months. The rainfall varies from $400 \mathrm{~mm}$ in inland to $1,200 \mathrm{~mm}$ on the coast, while the annual potential evaporation varies from 2,400 $\mathrm{mm}$ in the coast, to 3,000 $\mathrm{mm}$ inland; $80 \%$ of the precipitation on the state is centered around March to May, when it's main rainfall system (ITCZ) reaches the southernmost position. The dominant climate is Köppen Aw' in the coast and inland. In the mountains of Baturité, where is located the Guaramiranga station, the climate is Köppen Amw' (Funceme, 2014).

Since there are no perennial rivers in Ceará, the only way to provide water for all needs, is from the stock of water accumulated in surface reservoirs (Campos; Studart; Costa, 2000), which are highly vulnerable to the effects of evaporation. Despite the chronic water scarcity, the demand for irrigation follows worldwide standards and represents around $62 \%$ of the total water demand in the state (ANA, 2012).

\subsection{Data collection}

There are 12 weather stations belonging to INMET in the state of Ceará which continuously record the meteorological parameters from January 1961 to December 2015. Of these 12 stations, only eight had monthly (mean daily data for each month) records of the required parameters to estimate $\mathrm{ET}_{0}$, namely: [1] $\mathrm{T}_{\max }$ : maximum average temperature $\left({ }^{\circ} \mathrm{C}\right)$; [2] $\mathrm{T}_{\text {min }}$ : minimum average temperature $\left({ }^{\circ} \mathrm{C}\right) ;[3] \mathrm{U}$ : wind speed at $10 \mathrm{~m}$ height $\left(\mathrm{m} \mathrm{s}^{-1}\right)$; 


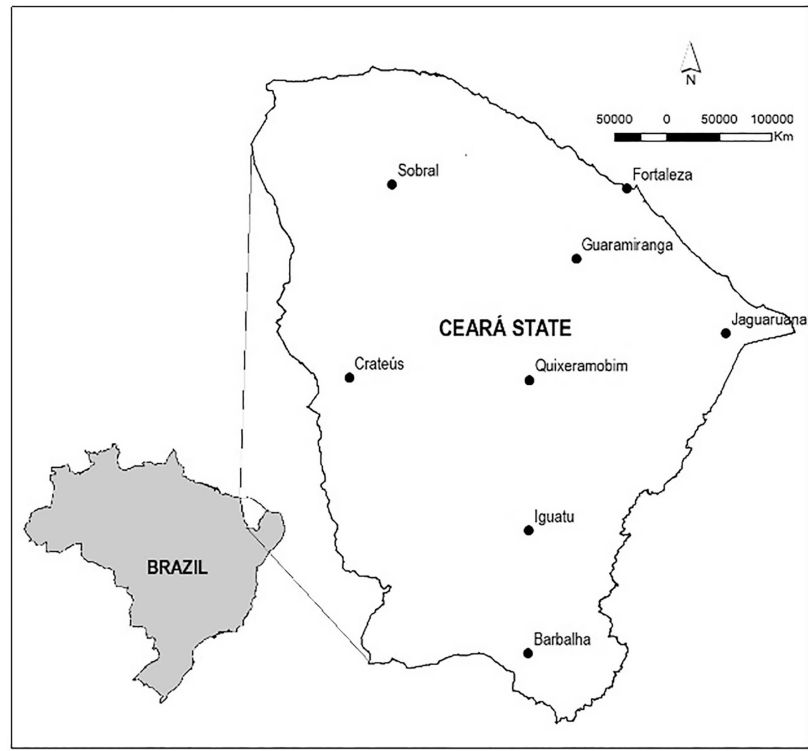

Figure 1 - Location of the study area and spatial distribution of meteorological stations in Ceará State map.

[4] S: sunshine hours (h) and [5] RH: relative humidity (\%) (Figure 1; Table 1) (INMET, 2016).

Even though the historical data covers 55 years of measurements (1961 - 2015), there are many gaps in the data for some of the climatic variables. To be able to estimate the $\mathrm{ET}_{0}$, it is necessary to have data for all climatic variables affecting $\mathrm{ET}_{0}$. For this reason, the length of the data set was reduced. Depending on the station, the time span observed was from 15 to 31 years. For each station the percent availability of each meteorological variable was determined (Table 2). It may be noted that in Crateus, for instance, only $29 \%$ of the time series can be used (16 years). For Fortaleza however, $56 \%$ of the data collected could be used (31 years).

\subsection{ET $_{0}$ estimation}

The annual $\mathrm{ET}_{0}$ was calculated using the standard Penman-Monteith Method (PM) as recommended by the United Nations Food and Agriculture Organization (FAO) (Allen et al., 1998). PM has been applied successfully in many arid and semi-arid regions (Shadmani; Marofi; Rokinian, 2012), and is considered the most reliable method for various climates, once it is physically based on and explicitly incorporates both physiological and aerodynamic parameters (Xu et al., 2006).

The software SEVAP (Silva et al., 2005) was employed for the estimation of the PM reference evapotranspiration. Non-available meteorological variables in routine observations in conventional stations (necessary in PM Method) is estimated by SEVAP using maximum and minimum temperatures, wind speed, sunshine hours and relative humidity.

Table 1 - Geographic and climatic characteristics of the climatology (annual mean) stations used in the study (adapted from INMET, 2016).

\begin{tabular}{|c|c|c|c|c|c|c|c|c|c|}
\hline Code & Station & Latitude $\left({ }^{\circ}\right)$ & Longitude $\left({ }^{\circ}\right)$ & Elevation (m) & $\mathrm{T}_{\max }\left({ }^{\circ} \mathrm{C}\right)$ & $\mathrm{T}_{\min }\left({ }^{\circ} \mathrm{C}\right)$ & $\mathrm{U}\left(\mathrm{ms}^{-1}\right)$ & S (h) & RH (\%) \\
\hline 82784 & Barbalha & -7.3 & -39.3 & 409.0 & 32.2 & 20.7 & 1.8 & 8.0 & 67.7 \\
\hline 82583 & Crateus & -5.2 & -40.7 & 296.8 & 32.2 & 22.0 & 2.9 & 7.5 & 60.7 \\
\hline 82397 & Fortaleza & -3.8 & -38.5 & 26.5 & 30.6 & 23.6 & 3.3 & 7.9 & 78.2 \\
\hline 82487 & Guaramiranga & -4.3 & -39.0 & 870.7 & 25.7 & 18.1 & 2.7 & 5.1 & 86.6 \\
\hline 82686 & Iguatu & -6.4 & -39.3 & 217.7 & 33.2 & 22.2 & 2.4 & 8.3 & 62.9 \\
\hline 82493 & Jaguaruana & -4.8 & -37.8 & 11.7 & 33.4 & 22.9 & 3.6 & 8.3 & 71.1 \\
\hline 82586 & Quixeramobim & -5.2 & -39.3 & 79.5 & 33.2 & 22.7 & 3.3 & 8.0 & 65.1 \\
\hline 82392 & Sobral & -3.7 & -40.3 & 109.6 & 34.0 & 22.2 & 2.0 & 7.4 & 69.2 \\
\hline
\end{tabular}

Table 2 - Availability of data from meteorological stations and variables of the amount of calculated $\mathrm{ET}_{0}$.

\begin{tabular}{llcccccccc}
\hline Code & Station & $\mathrm{T}_{\max }$ & $\mathrm{T}_{\min }$ & $\mathrm{U}$ & $\mathrm{S}$ & $\mathrm{RH}$ & $\mathrm{ET}_{0}$ & Years Available & $\mathrm{N}^{\mathrm{o}}$ years \\
\hline 82784 & Barbalha & $55 \%$ & $49 \%$ & $51 \%$ & $44 \%$ & $47 \%$ & $35 \%$ & $1974,1976,1978,1981,1984,1996,1997,1999,2003-2007,2009-2014$ & 19 \\
82583 & Crateus & $47 \%$ & $49 \%$ & $47 \%$ & $38 \%$ & $44 \%$ & $29 \%$ & $1970,1973,1975,1977-1978,1996,1998-1999,2006-2008,2011-2012$ & 16 \\
82397 & Fortaleza & $56 \%$ & $56 \%$ & $56 \%$ & $64 \%$ & $56 \%$ & $56 \%$ & $1961-1962,1965-1970,1973-1978,1982,1994,1996-1997,1999,2003-2014$ & 31 \\
82487 & Guaramiranga & $64 \%$ & $64 \%$ & $53 \%$ & $53 \%$ & $60 \%$ & $35 \%$ & $1961-1962,1969,1976,1978,1997-1998,2002-2007,2009-2014$ & 19 \\
82686 & Iguatu & $60 \%$ & $62 \%$ & $49 \%$ & $55 \%$ & $53 \%$ & $42 \%$ & $1963-1971,1973,1978,1997,2001,2005-2014$ & 14 \\
82493 & Jaguaruana & $60 \%$ & $56 \%$ & $47 \%$ & $55 \%$ & $49 \%$ & $42 \%$ & $1995-1997,2003-2014$ & 23 \\
82586 & Quixeramobim & $62 \%$ & $64 \%$ & $62 \%$ & $47 \%$ & $64 \%$ & $36 \%$ & $1961-1963,1968-1970,1974,1978,1996,1999,2006-2015$ & 19 \\
82392 & Sobral & $64 \%$ & $64 \%$ & $49 \%$ & $58 \%$ & $55 \%$ & $35 \%$ & $1961-1962,1969-1970,1973-1975,1978,2004-2014$ & 19 \\
\hline
\end{tabular}




\subsection{Trend analysis}

To detect trends, two statistical tests were applied in this investigation: Mann-Kendall and regression analysis. The Mann-Kendall test is a nonparametric test, highly recommended by the World Meteorological Organization (WMO) for the analysis of hydro-meteorological time series, because assumptions about the underlying probability distribution function of the data are not necessary (Wang, 2011). Regression analysis is a classical statistical test for the detection of trends in time data sets that provides an estimative for the trend value.

\subsubsection{Linear regression analysis}

Linear regression analysis is applied for detecting trends in the climate variables time series. The main statistical parameter drawn from the regression analysis, the slope, shows temporal trends in the average of the climate variable. For a time series of a climate variable $\mathrm{Y}$, the Eq. (1):

$$
Y_{i}=a+b t_{i}+\varepsilon_{i}
$$

where $Y i$ is the value of climate variable at time $\mathrm{t}$; $a$ is the value of Y for $t=0 ; b$ is the slope, $t_{i}$ is the time and $\varepsilon$ is white noise. To verify the limits of confidence and test of significance is applied the test for $b$ as a random variable with a t of Student distribution (Storch et al., 1999).

\subsubsection{Mann-Kendall Test}

This statistic test was originally developed by Mann (1945) as a non-parametric test for trends. The test was later modified by Kendall (1975). The Mann-Kendall test (MK) has been used since then and is considered an effective tool for identifying trends in hydrologic variables. The method offers many advantages because missing values are allowed, and the data is not required to conform to any particular distribution (Salmi et al., 2002), furthermore it is less sensitive to outliers (Hamed, 2008). MK, based on $\mathrm{S}$ statistics, compares each value of the time series with its own future values, always in sequential order (Eq. (2)). Autocorrelation in time series can affect the sensitivity of this method, and so, it must be verified (Silva, 2015).

$$
S=\sum_{i=1}^{n-1} \sum_{j=i+1}^{n} \operatorname{sgn}\left(X_{j}-X_{i}\right)
$$

where $x_{j}$ - the sequential data values; $n$ - the length of the data set; $s g n$ - equal to 1,0 or -1 , if $\left(x_{j^{-}} x_{i}\right)$ is greater than, equal to or less than zero, respectively.

The null hypothesis $\left(\mathrm{H}_{0}\right)$ is that the data $\left(\mathrm{x}_{1}, \ldots \mathrm{x}_{\mathrm{n}}\right)$ is identically distributed with random variables (i.e. no existing trend in the data set). The alternative hypothesis $\left(\mathrm{H}_{1}\right)$ is that there is a trend.

It can be shown that $\mathrm{S}$ is normally distributed, i.e., $\mathrm{S}^{\sim}$ $N\left(\mu, \sigma^{2}\right)$. For several observations greater than ten $(n>10)$ the test statistic is calculated (Eq. (3)) (Önöz; Bayazit, 2003):

$$
Z= \begin{cases}S-1 / \sigma_{s} & \text { if } S>0 \\ 0 & \text { if } S=0 \\ S+1 / \sigma_{s} & \text { if } S<0\end{cases}
$$

were $\sigma_{s}=\sqrt{\frac{n(n-1)(2 n+5)}{18}}$

The null hypothesis, no trend, is rejected when the computed $Z$ value is greater than $Z_{\alpha / 2}$ in absolute numbers. The $Z$ statistic signal indicates whether the trend is increasing $(Z>0)$ or descending $(Z<0)$. The significance level was set to 0.05 , which is widely used in the literature (Wang, 2011; Li et al., 2013; Gocic; Trajkovic, 2013; Zhang et al., 2015).

\section{Results and Discussion}

The autocorrelation of the time series was checked for each variable. Only Guaramiranga station presented negative significance, at 5\% significance level, an autocorrelation on lag 1 . For a better discussion and understanding of the spatial and temporal trends in the five intervening variables, as well as in the $\mathrm{ET}_{0}$, tables and graphics containing the results of MK tests (Tables 3 to 6) and of the linear regression $(\beta)$ were applicable (hatched lines).

\subsection{Maximum $\left(T_{\max }\right)$ and minimum $\left(T_{\min }\right)$ temperature}

A significant increasing trend $(Z)$ was observed in $\mathrm{T}_{\max }$ for six stations - Barbalha, Crateus, Fortaleza, Iguatu, Quixeramobim, and Sobral (Table 3) For $\mathrm{T}_{\min }$ a significant increasing trend in three stations was observed - Crateus, Fortaleza, and Guaramiranga. No significant decreasing trend for these variables was detected in any station. These results are consistent to rising surface air temperature

\begin{tabular}{|c|c|c|c|c|c|c|}
\hline \multirow[t]{2}{*}{ Station } & \multicolumn{3}{|c|}{$\begin{array}{l}\text { Maximum temperature } \\
\qquad\left(\mathrm{T}_{\max }\right)\end{array}$} & \multicolumn{3}{|c|}{$\begin{array}{l}\text { Minimum temperature } \\
\qquad\left(\mathrm{T}_{\min }\right)\end{array}$} \\
\hline & $\mathrm{Z}$ & Trend & $\begin{array}{c}\beta\left({ }^{\circ} \mathrm{C}\right. \\
\left.\text { year }^{-1}\right)\end{array}$ & Z & Trend & $\begin{array}{c}\beta\left({ }^{\circ} \mathrm{C}\right. \\
\left.\text { year }^{-1}\right)\end{array}$ \\
\hline Barbalha & 4.07 & $\mathrm{~S}+$ & 0.042 & 1.17 & NS & 0.024 \\
\hline Crateus & 2.47 & $\mathrm{~S}+$ & 0.026 & 3.13 & $\mathrm{~S}+$ & 0.025 \\
\hline Fortaleza & 5.20 & $\mathrm{~S}+$ & 0.029 & 2.99 & $\mathrm{~S}+$ & 0.012 \\
\hline Guaramiranga & 0.48 & NS & 0.004 & 4.99 & $\mathrm{~S}+$ & 0.030 \\
\hline Iguatu & 2.22 & $\mathrm{~S}+$ & 0.016 & 1.19 & NS & 0.004 \\
\hline Jaguaruana & 1.10 & NS & 0.020 & 1.48 & NS & 0.015 \\
\hline Quixeramobim & 1.85 & $\mathrm{~S}+$ & 0.022 & 1.27 & NS & 0.004 \\
\hline Sobral & 2.36 & $\mathrm{~S}+$ & 0.026 & -1.59 & NS & -0.005 \\
\hline
\end{tabular}
recently found in urban and nearby areas (Ren, 2015).

Table 3 - MK results and linear regression of $T_{\max }$ and $T_{\min }$. 
The linear regression coefficient $(\beta)$ revealed, at $5 \%$ significance level, increases in $\mathrm{T}_{\max }$, ranging from $0.16^{\circ} \mathrm{C}$ per decade in Iguatu to $0.42{ }^{\circ} \mathrm{C}$ per decade in Barbalha. These values are much smaller than those found in Serbia, which are around $6{ }^{\circ} \mathrm{C}$ per decade (Gocic and Trajkovic, 2013), but are in the same range of those detected in the Brazilian Amazon region, around $0.15{ }^{\circ} \mathrm{C}$ per decade (Gocic and Trajkovic, 2013) and Iran, around $0.7^{\circ} \mathrm{C}$ per decade (Tabari and Marofi, 2011).

For $T_{\min }$, the lowest increase was in Fortaleza $\left(0.12^{\circ} \mathrm{C}\right.$ per decade) and the largest was in Guaramiranga $\left(0.30^{\circ} \mathrm{C}\right.$ per decade). These values are lower than those found in Iran, around $1.2{ }^{\circ} \mathrm{C}$ per decade (Tabari and Marofi, 2011) and Serbia, around almost $4{ }^{\circ} \mathrm{C}$ per decade (Gocic and Trajkovic, 2013), but are in the same range of those detected in the Brazilian Amazon region, between 0.41 and $0.72{ }^{\circ} \mathrm{C}$ per decade (Silva, 2015). Davis and Hanna (2016) also detected a tendency of increase in the maximum and minimum temperatures in Australia. All these authors linked these growing trends to global warming, increase in urban areas, and changes in atmospheric circulation.

\subsection{Wind speed (U) and sunshine hours (S)}

In the data for the annual wind speed and sunshine hours for the 1961 to 2015 period there is a significant increasing trend in wind speed in three stations - Crateus, Iguatu and Quixeramobim and a significant downward trend in Barbalha and Fortaleza. There is a significant increasing trend in sunshine hours in two stations - Iguatu and Sobral; as well as a significant declining trend in Guaramiranga (Table 4).

The coefficient $\beta$ revealed, at the level of significance of $5 \%$, an increase in $\mathrm{U}$, ranging from $0.10 \mathrm{~m} \mathrm{~s}^{-1}$ per decade in Crateus to $0.25 \mathrm{~m} \mathrm{~s}^{-1}$ per decade in Quixeramobim. A decrease of 0.11 and $0.13 \mathrm{~m} \mathrm{~s}^{-1}$ per decade is

Table 4 - MK results and linear regression of wind speed and sunshine. The gray-shaded lines correspond to positive significant trend.

\begin{tabular}{|c|c|c|c|c|c|c|}
\hline \multirow[t]{2}{*}{ Station } & \multicolumn{3}{|c|}{ Wind speed (U) } & \multicolumn{3}{|c|}{ Sunshine hours (S) } \\
\hline & Z & Trend & $\beta\left(\mathrm{m} \mathrm{s}^{-1}\right.$ year $\left.^{-1}\right)$ & Z & Trend & $\begin{array}{c}\beta(\mathrm{h} \\
\left.\text { year }^{-1}\right)\end{array}$ \\
\hline Barbalha & -3.73 & S- & -0.013 & 0.77 & NS & 0.012 \\
\hline Crateus & 2.89 & $\mathrm{~S}+$ & 0.010 & 0.21 & NS & 0.000 \\
\hline Fortaleza & -2.28 & S- & -0.011 & 0.00 & NS & 0.000 \\
\hline Guaramiranga & 0.66 & NS & 0.040 & -2.64 & S- & -0.019 \\
\hline Iguatu & 2.34 & $\mathrm{~S}+$ & 0.017 & 2.69 & $\mathrm{~S}+$ & 0.011 \\
\hline Jaguaruana & -1.59 & NS & -0.009 & 0.68 & NS & 0.012 \\
\hline Quixeramobim & 3.47 & $\mathrm{~S}+$ & 0.025 & 1.14 & NS & 0.006 \\
\hline Sobral & 0.58 & NS & -0.006 & 3.68 & $\mathrm{~S}+$ & 0.024 \\
\hline
\end{tabular}

NS $=$ not significant trend; $\mathrm{S}+=$ positive significant trend $(5 \%) ; \mathrm{S}-=$ significant negative trend $(5 \%) . Z=M K$ significance; $\beta=$ linear regression coefficient. observed in Fortaleza and Barbalha. These values are close to those found in China, around $0.1 \mathrm{~m} \mathrm{~s}^{-1}$ per decade (Liu et al., 2011) and Serbia, around $1.2 \mathrm{~m} \mathrm{~s}^{-1}$ per decade (Gocic and Trajkovic, 2013), and lower than those detected in China by Ye et al. (2014), around $0.2 \mathrm{~m} \mathrm{~s}^{-1}$ per decade.

For the sunshine hours (S), the coefficient $\beta$ revealed, for the same level of significance, an increase of $0.11 \mathrm{~h}$ per decade in Iguatu station and $0.24 \mathrm{~h}$ per decade in Sobral. A decrease of $0.19 \mathrm{~h}$ was observed in Guaramiranga. These values are similar to those detected in China, around $-0.2 \mathrm{~h}$ per decade (Ye et al., 2014), and the Brazilian Amazon region, between 0.2 and $0.5 \mathrm{~h}$ per decade (Silva, 2015).

\subsection{Relative humidity (RH)}

The annual trends in the relative humidity (RH) for the 1961 to 2015 period demonstrate a significant downward trend in two stations - Crateus and Iguatu and only a significant increasing trend in Barbalha (Table 5).

The linear regression coefficient revealed, at the level of significance of $5 \%$, a decrease in relative humidity (RH) of $0.86 \%$ per decade in Crateus and $0.85 \%$ per decade in Iguatu; an increase of $2.11 \%$ per decade is observed in Barbalha. These values are higher than those found in China, between -0.3 and $0.5 \%$ per decade (Huo et al., 2013; Ye et al., 2014), but similar to those reported in the Brazilian Amazon region, around $2.2 \%$ per decade by Silva (2015).

The trends on maximum average temperature, minimum average temperature, wind speed, sunshine hours and relative humidity for Iguatu station are presented in Figure 2.

\subsection{Evapotranspiration $\left(\mathrm{ET}_{\mathbf{0}}\right)$}

For annual trends in evapotranspiration $\left(\mathrm{ET}_{0}\right)$ for the 1961 to 2015 period there is a significant increasing trend

Table 5 - MK results and linear regression for humidity.

\begin{tabular}{lccc}
\hline Climatology Station & \multicolumn{3}{c}{ Relative humidity } \\
\cline { 2 - 4 } & $\mathrm{Z}$ & Trend & $\beta\left(\%\right.$ year $\left.^{-1}\right)$ \\
\hline Barbalha & 2.56 & $\mathrm{~S}+$ & 0.211 \\
Crateus & -1.81 & $\mathrm{~S}-$ & -0.086 \\
Fortaleza & -1.29 & $\mathrm{NS}$ & -0.038 \\
Guaramiranga & -1.35 & $\mathrm{NS}$ & -0.027 \\
Iguatu & -2.31 & $\mathrm{~S}-$ & -0.085 \\
Jaguaruana & -0.77 & $\mathrm{NS}$ & -0.025 \\
Quixeramobim & 0.68 & $\mathrm{NS}$ & 0.017 \\
Sobral & -1.57 & $\mathrm{NS}$ & -0.056 \\
\hline
\end{tabular}

$\mathrm{NS}=$ not significant trend; $\mathrm{S}+=$ positive significant trend $(5 \%) ; \mathrm{S}-=$ significant negative trend $(5 \%) . Z=M K$ significance; $\beta=$ linear regression coefficient. The gray-shaded lines correspond to positive significant trend. 
in three stations - Crateus, Fortaleza, and Iguatu (Table 6). No station showed a significant downward trend for $\mathrm{ET}_{0}$. The MK test was not applied to Guaramiranga station, since it presented a negative correlation on lag -1 . Thus, the other tests were not performed.

The coefficient $\beta$ revealed, at the level of significance of $5 \%$, an increase in $\mathrm{ET}_{0}$ of $37.9 \mathrm{~mm}$ per decade in Crateus, $47.4 \mathrm{~mm}$ per decade in Iguatu and $5.5 \mathrm{~mm}$ per decade in Fortaleza. These values are higher than those found in the Brazilian Amazon region, between 0.06 and $0.15 \mathrm{~mm}$ per decade (Silva et al., 2015) and in China, around $-30.9 \mathrm{~mm}$ per decade (Huo et al., 2013), but similar to those detected in some stations of Iran by Kousari et al. (2013). The trend on $\mathrm{ET}_{0}$ for Iguatu Station is presented in Figure 3.
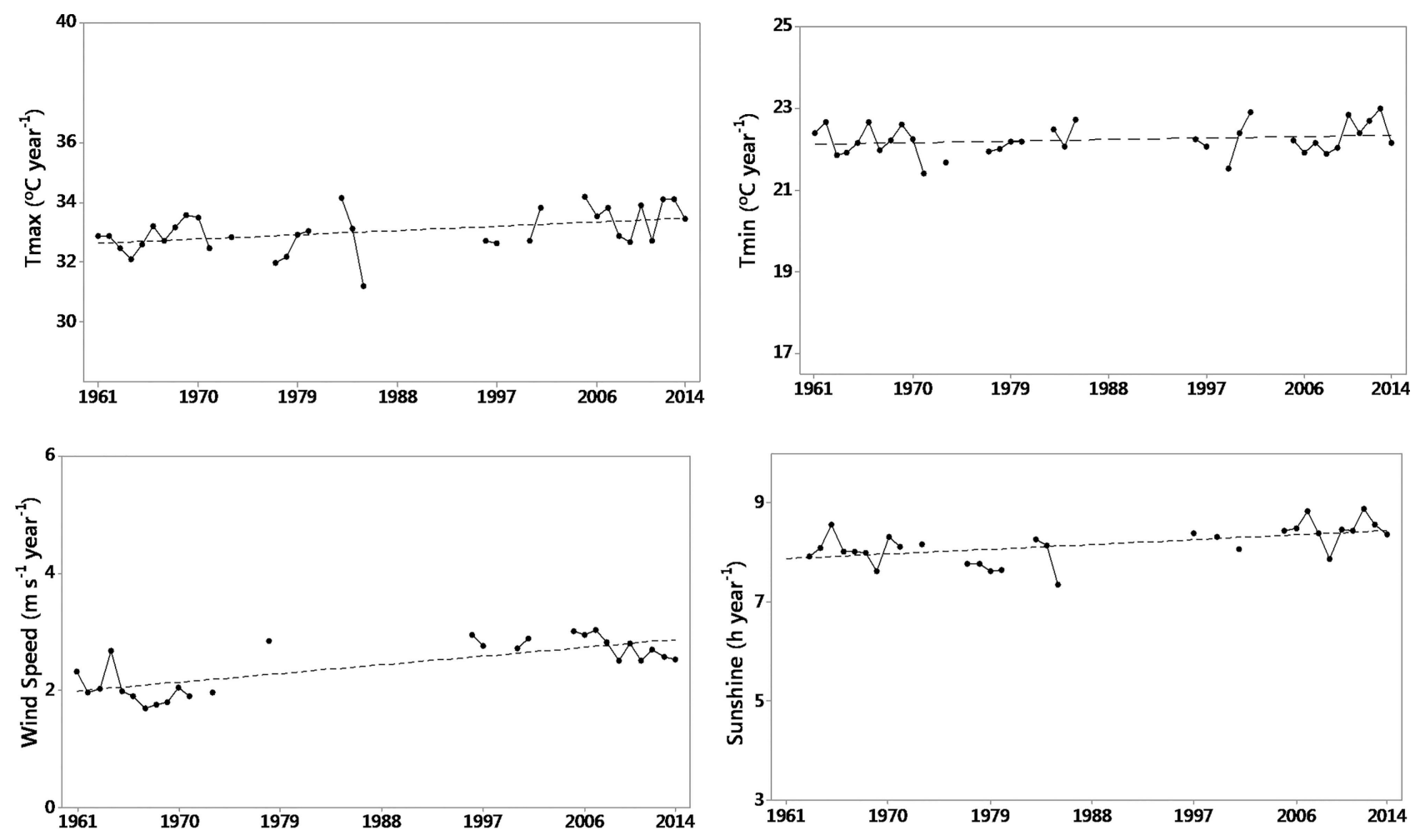

Table 6 - MK results and linear regression of evapotranspiration.

\begin{tabular}{lccc}
\hline Climatology Station & \multicolumn{3}{c}{ Evapotranspiration } \\
\cline { 2 - 4 } & $\mathrm{Z}$ & Trend & $\beta\left(\mathrm{mm} \mathrm{year}^{-1}\right)$ \\
\hline Barbalha & -1.40 & $\mathrm{NS}$ & -1.31 \\
Crateus & 1.94 & $\mathrm{~S}+$ & 3.79 \\
Fortaleza & 1.80 & $\mathrm{~S}+$ & 0.55 \\
Guaramiranga & $*$ & $*$ & $*$ \\
Iguatu & 3.49 & $\mathrm{~S}+$ & 4.74 \\
Jaguaruana & 0.10 & $\mathrm{NS}$ & 0.27 \\
Quixeramobim & 1.59 & $\mathrm{NS}$ & 2.78 \\
Sobral & 1.19 & $\mathrm{NS}$ & 1.79 \\
\hline
\end{tabular}

$\mathrm{NS}=$ not significant trend; $\mathrm{S}+=$ positive significant trend $(5 \%) ; \mathrm{S}-=$ significant negative trend $(5 \%) . Z=M K$ significance; $\beta=$ linear regression coefficient. The gray-shaded lines correspond to positive significant trend.

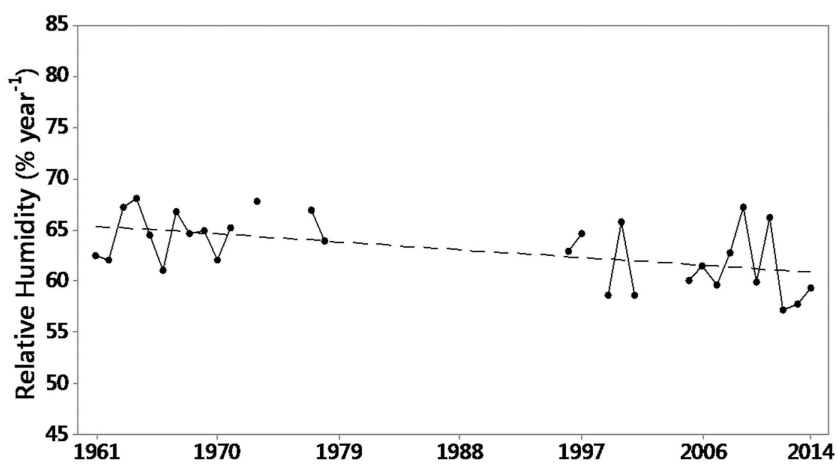

Figure 2 - Average annual climatological variables (round dotted line) over time with the linear regression line of the Iguatu station. 
The Table 7 shows a summary of the trends behavior (increasing or decreasing) in regard to $\mathrm{ET}_{0}$, as well as in the defining variables (air temperature, wind speed, relative humidity and sunshine hours). It demonstrates that the variables display predominantly positive trends. However, only in three stations the increase in $\mathrm{ET}_{0}$ period was directly affected by them.

Some increasing trends observed in the meteorological records may express more local effects than global change (Back, 2001). The heat due to urbanization produces the warming of the atmosphere that affects the temperature, since most of the meteorological stations are close to the urban areas. Figure 4 shows the growth of urban areas in Iguatu for the period 1984 to 2011 (area passing from 375 ha to $1,162 \mathrm{ha}$ ). However, Crateus and Iguatu still have some rural characteristics (few concrete and asphalt pavements) and displayed an increasing trend in $\mathrm{T}_{\max }$ and $\mathrm{T}_{\text {min }}$, variables that respond strongly to global warming (Tang et al., 2010). Increased $\mathrm{T}_{\min }$ results in a decrease in daily temperature range and warmer nights, a fact already observed in various regions of the world that are not affected by mega cities, since concrete and asphalt pavements directly influence the diurnal temperature variation
(Marengo; Rusticucci; Penalba, 2010). In the Fortaleza station, vertical urbanization on the north-northeast coast of the city influenced the negative trend of the wind variable, a fact not observed in the other regions of the State.

It is difficult to establish the real cause of these increasing trends - climate change, urbanization or both). However, the main warning from these results is that $\mathrm{ET}_{0}$ is increasing in the inland (Iguatu and Crateus stations). This means that water demand for irrigation is expected to significantly increase over the next decades due higher $\mathrm{ET}_{0}$ rates. It is also important to point out the relative importance of irrigation in Jaguaribe River Basin (where Iguatu station is located), which corresponds to $83 \%$ of its total water demand - 37\% (private irrigation) and 46\% (public irrigation projects) (Studart et al., 2000).

\section{Conclusion}

Trend analyses of $\mathrm{ET}_{0}$ and of its underlying meteorological variables were conducted for eight meteorological stations in Ceará State, located in semi-arid Northeast Brazil, using the Mann-Kendall test and linear regression analysis. The trends found in some climate variables were aggregated in the annual average

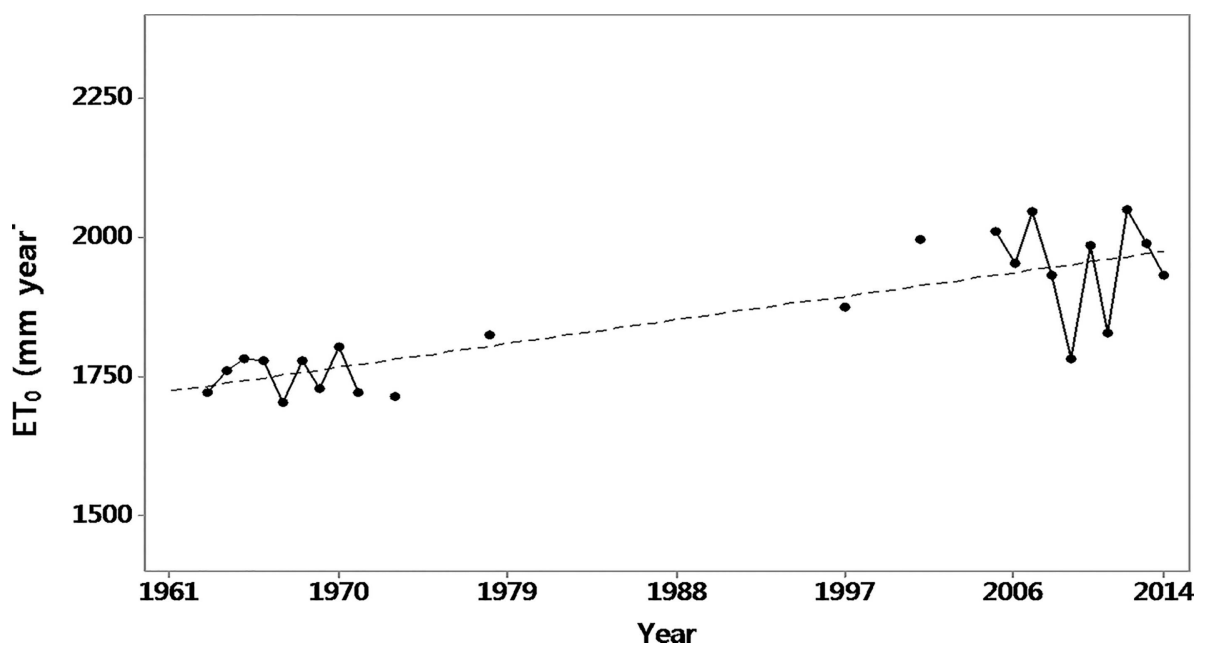

Figure 3 - Average annual evapotranspiration (round dotted line) over time with the linear regression line of the Iguatu station.
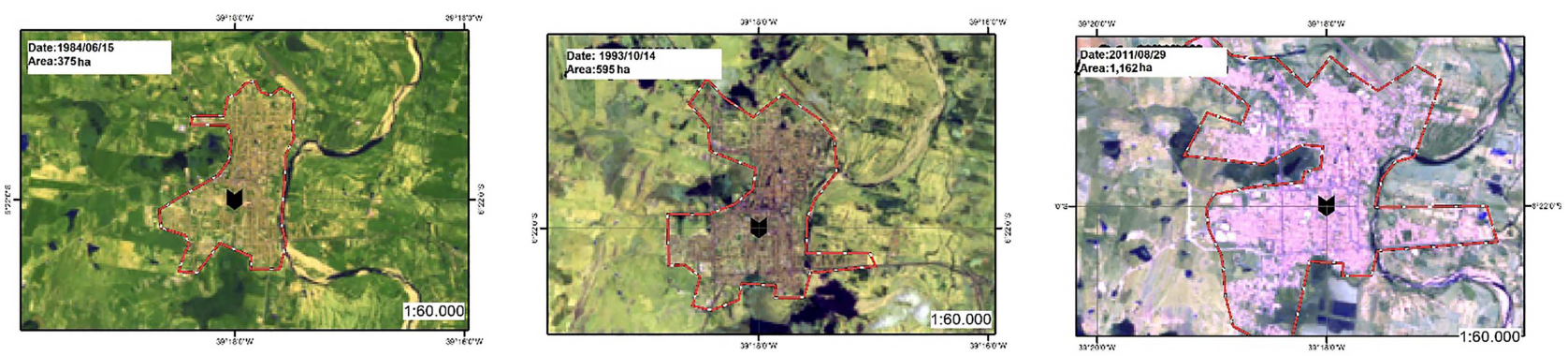

Figure 4 - Urban area evolution in Iguatu (1984 to 2011). 


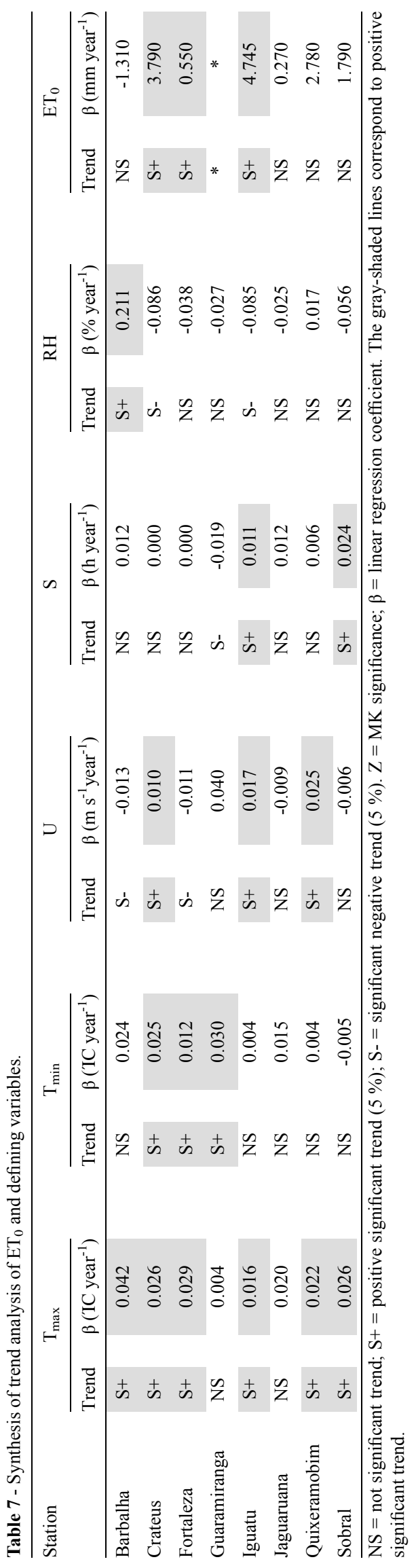

evapotranspiration $\mathrm{ET}_{0}$, which is variable most related to the water demand for irrigation.

The most relevant results were the positive trends in $\mathrm{ET}_{0}$ in three of the eight stations: $47.4 \mathrm{~mm}$ per decade in Iguatu; $37.9 \mathrm{~mm}$ per decade in Crateus, and $5.5 \mathrm{~mm}$ decade in Fortaleza. These upward trends point out increases in annual $\mathrm{ET}_{0}$ of $2.6 \%, 2.0 \%$ and $0.3 \%$ per decade, respectively. It should be observed that the higher increases in evapotranspiration happens in the interior of the state, Crateus and Iguatu, places frequently impacted by severe droughts. Iguatu station, which presented the highest $\mathrm{ET}_{0}$ rate is in the Jaguaribe River Basin, where the irrigation demand is greater than $80 \%$ of its total water demand.

Other studies that compare changes in water demand with changes in water availability are still necessary for the development of better climate adaptation policies. Nevertheless, climatic data should warn and alarm society that new practices that increase sustainability are necessary and urgently required.

\section{Acknowledgements}

The authors wish to thank INMET for providing the meteorological data used in this study and would also like to thank the Cearense Foundation for the Support of Scientific and Technological Development (FUNCAP) for the financial support for this research.

\section{References}

ALLEN R.G.; PEREIRA L.S.; RAES D.; SMITH M. Crop evapotranspiration: guideline for computing crop water requirement. FAO Irrigation and drainage Paper No. 56. FAO: Rome, Italy, 1998. Available at: [http://www.fao.org/ docrep/x0490e/x0490e00.htm]. Accessed on: [Feb, 2016].

ALVES, J.M.B.; SERVAIN, J.; CAMPOS, J.N.B. Relationship between ocean climatic variability and rain-fed agriculture in northeast Brazil, Climate Research, v. 38, n. 3, p. 225236, 2009.

BACK, A. J. Aplicação de análise estatística para identificação de tendências climáticas. Pesq. agropec. bras., v. 36, n. 5, p. 717-726, 2001

AGÊNCIA NACIONAL DE ÁGUAS (ANA). A Questão da Água no Nordeste / Centro de Gestão e Estudos Estratégicos, Brasília: Agência Nacional de Águas, 2012, 432 p.

BANDYOPADHAYAY, A., BHADRA, A.; RAGHUWANSHI, N.S.; SINGH, R. Temporal trends in estimates of reference evapotranspiration over India. Journal of Hydrologic Engineering, v. 14, n. 5, p. 508-518, 2009.

BORMANN, H. Sensitivity analysis of 18 different potential evapotranspiration models to observed climatic change at German climate stations. Climate Change, v. 104, n. 3-4, p. 729-753, 2011.

CAMPOS, J.N.B.; STUDART, T.M.C.; COSTA, A.M. Some thoughts on water management and initial allocation of 
water rights in Ceará, Brazil. In: International Conference On Hydro-Sciences and Engineering, v. 4, 2000.

DAVIS, C.J.; HANNA, E.G. Temperature and rainfall trends in northern Australia 1911-2013: implications for human activity and regional development. Climate Research, v. 71, n. 1, p. 1-16, 2016.

DINPASHOH, Y.; JHAJHARIA, D.; FAKHERI-FARD, A.; SINGH, V.P.; KAHYA, E. Trends in over Iran. Journal of Hydrology, v. 399, n. 3, p. 422-433, 2011.

FOOD AND AGRICULTURE ORGANIZATION (FAO). http:// www.fao.org/nr/water/aquastat/tables/WorldData-Withdrawal_eng.pdf, accessed on: Dec, 2016.

GOCIC, M.; TRAJKOVIC, S. Analysis of changes in meteorological variables using Mann-Kendall and Sen's slope estimator statistical tests in Serbia. Global Planetary Change, v. 100, n. 1, p. 172-182, 2013.

HAMED, K.H. Trend detection in hydrologic data: The MannKendall trend test under the scaling hypothesis. Journal of Hydrology, v. 349, n. 3-4, p. 350-363, 2008.

HUO, Z.L.; DAI, X.Q.; FENG, S.Y.; KANG, S.Z.; HUANG, G. $\mathrm{H}$. Effect of climate change on reference evapotranspiration and aridity index in arid region of China. Journal of Hydrology, v. 492, p. 24-34, 2013.

INTERGOVERNMENTAL PANEL ON CLIMATE CHANGE (IPCC). Climate Change 2014: Synthesis Report. Contribution of Working Groups I, II and III to the Fifth Assessment Report of the Intergovernmental Panel on Climate Change. Core Writing Team, Pachauri, R.K. and Meyer, L.A. (eds.). IPCC, Geneva, 151 pp, 2014.

INSTITUTO NACIONAL E METEOROLOGIA (INMET). http://www.inmet.gov.br/portal/index.php?r=bdmep/ bdmep, accessed on: Feb, 2016

IRMAK, S.; KABENGE, I.; SKAGGS, K.E.; MUTIIBWA, D. Trend and magnitude of changes in climate variables and reference evapotranspiration over 116-yr period in the Platte River Basin, central Nebraska - USA. Journal of Hydrology, v. 420, n. 421, p. 228-244, 2012.

KENDALL, M.G. Rank correlation methods. London: Charles Griffin, 1975.

KOUSARI, M.R.; ZARCH, M.A.A.; AHANI, H.; HAKIMELAHI, H. A survey of temporal and spatial reference crop evapotranspiration trends in Iran from 1960 to 2005. Climate Change, v. 120, n. 1-2, p. 277-298, 2013.

LI, X.; GEMMER, M.; ZHAI, J.; LIU, X.; SU, B.; WNAG, Y. Spatio-temporal variation of actual evapotranspiration in the haihe river basin of the past 50 years. Quaternary International, v. 304, n. 1, p. 133-141, 2013.

LIU, X.; LUO, Y.; ZHANG, D.; ZHANG, M.; LIU C. Recent changes in pan-evaporation dynamics in China, Geophysical Research Letters, v. 38, L13404, 2011.

LV, M.Q.; CHEN, J.L.; MIRZA, Z.A.; CHEN, C.D.; WEN, Z.F.; JIANG, Y.; MA, M.H.; WU, S.J. Spatial distribution and temporal variation of reference evapotranspiration in the Three Gorges Reservoir area during 1960 - 2013. International Journal of Climatology, v. 36, n. 14, p. 4497-4511, 2016.

MANN, H.B. Non-parametric test against trend. Econometrica, v. 1, n. 3, p. 245-259, 1945.

MARENGO JA, RUSTICUCCI M, PENALBA O. An intercomparison of observed and simulated extreme rainfall and temperature events during the last half of the twentieth century: Part 2: historical trends. Climatic Change, v. 98, p. $509-529,2010$

ÖNÖZ, B.; BAYAZIT, M. The Power of Statistical Tests for Trend Detection. Turkish Journal of Engineering and Environmental Sciences, v. 27, p. 247-251, 2003.

PETERSON, T.C.; GOLUBEV, V.S.; GROISMAN, P.Y. Evaporation losing its strength. Nature, v. 337, p. 687-688, 1995.

REN, G. Urbanization as a major driver of urban climate change. Advances in Climate Change Research, v. 6, p. 1- 6, 2015.

SALMI, T.; MAATTA, A.; ANTTILA, P.; RUOHO-AIROLA, T.; AMNELL, T. Detecting Trends of Annual Values of Atmospheric Pollutants by the Mann-Kendall Test and Sen's Slope Estimates - the Excel Template Application MAKESENS, 2002. Finnish Meteorological Institute Publications on Air Quality No. 31. Helsinki, Finland. 35p, 2002.

SILVA, V.P.R.; BELO FILHO, A.F.; SILVA, B.B.; CAMPOS, J. H.B.C. Desenvolvimento de um sistema de estimativa da evapotranspiração de referência. Rev. bras. eng. agríc. ambient. v. 9, n. 4, p. 547-553, 2005.

SILVA H.J.F. Análise de tendência e caracterização sazonal e interanual da evapotranspiração de referência para o sudoeste da Amazônia brasileira: Acre, Brasil. MS Dissertation, Universidade Federal do Rio Grande do Norte, 107 p, 2015

SHADMANI, M.; MAROFI, S.; ROKNIAN, M. Trend analysis in reference evapotranspiration using Mann-Kendall and Spearman's Rho tests in arid regions of Iran. Water Resource Management, v. 206, p. 211-224, 2012.

SHAN, N.; SHI, Z.; YANG, X.; GAO, J.; CAI, D. Trends in potential evapotranspiration from 1960 to 2013 for a desertification-prone region of China. International Journal of Climatology, v. 36, n. 10, p. 3434-3445, 2015.

STUDART, T.M.C.; CAMPOS, J.N.B; VIEIRA, V.P.P.B.; CARVALHO, R.M. Water Demand Management in Semi-Arid Regions: The Case of Jaguaribe River Basin. In: 4th International Conference on Hydroscience and Engineering, Seoul, 2000.

TABARI, H.; MAROFI, S. Changes of pan evaporation in the west of Iran. Water Resources Management, v. 25, p. 97$111,2011$.

TABARI, H.; AEINI, A.; TALAEE, P.H.; SOME'E, B.S. Spatial distribution and temporal variation of reference evapotranspiration in arid and semi-arid regions of Iran. Hydrological Processes, v. 26, p. 500-512, 2012.

TANG, G.; DING, Y; WANG, S., REN, G.; LIU, H; ZHANG, L. Comparative Analysis of China Surface Air Temperature Series for the Past 100 Years. Advances in Climate Change Research, v. 1, n. 1, p. 11-19, 2010.

TEMESGEN, B.; ECHING, S.; DAVIDOFF, B.; FRAME, K. Comparison of some reference evapotranspiration equations for California. Journal of Irrigation and Drainage Engineering, v. 131, p. 73-84, 2005.

WANG, W.; PENG, S.; YANG, T.; SHAO, Q.; XU, J.; XING, W. Spatial and Temporal Characteristics of Reference Evapotranspiration Trends in the Haihe River Basin, China. 
Journal of Hydrological Engineering, v. 10, p. 239-252, 2011.

XU, C.Y.; GONG, L.; JIANG, T.; CHEN, D; SINGH, V.P. Analysis of spatial distribution and temporal trend of reference evapotranspiration and pan evaporation in Changjiang (Yangtze River) catchment. Journal of Hydrology, v. 327, n. 1, p. 81-93, 2006.

YE, X.; LI, X.; LIU, J.; XU, C.Y.; ZHANG, Q. Variation of reference evapotranspiration and its contributing climatic factors in the Poyang Lake catchment, China. Hydrological Processes, v. 28, p. 6151-6162, 2014.
ZHANG, K.X.; PAN, S.M.; ZHANG, W.; XU, Y.; CAO, L.; HAO, Y.; WANG, Y. Influence of climate change on reference evapotranspiration and aridity index and their temporal-spatial variations in the Yellow River Basin, China, from 1961 to 2012. Quaternary International, v. 380, n. 381 , p. $75-82,2015$.

This is an Open Access article distributed under the terms of the Creative Commons Attribution License, which permits unrestricted use, distribution, and reproduction in any medium, provided the original work is properly cited. 